$\xi \mathrm{p}$

\title{
Optimization of Vitamin a Nutrition of Calves Fattened on Wastes of Food Industry
}

\author{
Andrey Vladimirovich Valoshin ${ }^{1 *}$ \\ ${ }^{1}$ National Research Ogarev Mordovia State University, Bolshevistskaya St., 68, Saransk, 430005, Republic of Mordovia, Russian \\ Federation \\ *Corresponding author E-mail: valoshin.a.v@mail.ru
}

\begin{abstract}
The most important sources of fodder resources are wastes of food industry: pulp, distiller's grains, brewer's grains, malt sprouts, etc., which are widely used for cattle fattening.

The research was aimed at determining the optimal dosages of vitamin A in the diet of calves fattened on pulp, distiller's grains, brewer's grains, and malt sprouts.
\end{abstract}

\section{Keywords: feeding calves, vitamin A status of calves, digestibility of nutrients, calves' meat productivity.}

\section{Introduction}

At the present stage of animal husbandry development in Russia, one of the most important tasks is increasing beef production, improving the quality and reducing the costs. In the system of measures aimed at resolving this problem, the organization of biologically complete feeding of calves through the use of inhouse produced fodder and wastes of the food industry is very important. This means that calves should receive from the fodder all nutrients and biologically active substances in accordance with their needs at a certain physiological state and level of productivity. Among biologically active substances, an important role is played by vitamins, vitamin A in particular. In the organism of calves, it performs many vital functions. Shortage of vitamin A results in retardation of growth and development, metabolic disorders, reduced productivity, reduced feed-conversion efficiency, occurrence of diseases and death of the calves, which brings substantial economic losses to livestock [1].

In dairy and meat cattle breeding, in the structure of rations, a significant share is taken by coarse and succulent vegetable fodders that do not contain vitamin A, but contain its precursor, carotene, which produces vitamin $\mathrm{A}$ in the organisms of the animals. However, the use of excessive dosages of mineral fertilizers, especially nitrogen ones, pesticides, herbicides, contamination of fodder with salts of heavy metals, as well as violations in the technology of silage procurement and storage result in the destruction of carotene in the fodder, and deterioration of its absorption and conversion into vitamin A. This particularly applies to maize silage. In its turn, carotene is completely absent in the wastes of the food industry. Despite these circumstances, there are still no official standards for vitamin A for cattle. Its rationing is based on the quantitative content of carotene in the diet. At the same time, scientists have proven that carotene content in the diet does not reflect the true need of the livestock in vitamin A and its provision, and recommend introducing into the diets vitamin A supplements both separately and in the composition of AVMA, and premixes [2,3]. This is confirmed by numerous studies of the authors [4].

However, the issue of vitamin A dosages in relation to various conditions of animals' feeding remains unresolved. In this respect, studies aimed at determining the optimal level of vitamin A nutrition of livestock with regard to the type of the diet are relevant.

A characteristic feature of all types of fattening on food wastes is low content of carotene-containing precursors of vitamin $\mathrm{A}$ in the diet. Therefore, vitamin preparations are usually used for making up for the lack of vitamin A $[4,5]$.

Given the lack of standards for the need in vitamin A for cattle, it is important to develop optimal dosages and introducing vitamin A into the diet for a certain type of feeding.

\section{Methods}

The research was performed at LLC Niva in the Oktyabrsky district of the Republic of Mordovia. Out of all variants of behavior, diets of calves are the most important for the zootechnical practice.

For the scientific and economic experiments, calves at the age of 12-13 months were selected with the live weight with fattening on distillers' grains of $280-290 \mathrm{~kg}$, with fattening on pulp of 295-310 $\mathrm{kg}$, and with fattening on brewer's grains of 310-340 kg. For all types of fattening, 3 groups of 10 animals in each were formed according to the principle of analogues (age, live weight).

Feeding rations were made according to the norms of the RAAS $(1985,2003)$ and were intended for obtaining average daily gains when fattened on distiller's grains of $900 \mathrm{~g}$, on pulp and brewer's grains - of 1,000 g. (Tables 1-6).

Table 1: Feeding diets for fattening calves on distiller's grains

\begin{tabular}{|l|c|c|c|}
\hline \multicolumn{1}{|c|}{ Indicator } & \multicolumn{3}{|c|}{ Live weight, $\mathrm{kg}$} \\
\cline { 2 - 4 } & $300-350$ & $351-400$ & $401-450$ \\
\hline Diet: & 50 & 50 & 50 \\
bread distiller's grains, $\mathrm{kg}$ & 4 & 4 & 4 \\
spring straw, kg & 2.5 & 3 & 3.5 \\
barley groats, kg & & & \\
\hline
\end{tabular}




\begin{tabular}{|c|c|c|c|}
\hline feed chalk, g & 50 & 60 & 70 \\
\hline kitchen salt, $g$ & 40 & 48 & 55 \\
\hline copper sulfate, $\mathrm{mg}$ & 20 & 40 & 80 \\
\hline zinc sulphate, mg & 270 & 400 & 500 \\
\hline cobalt chloride, mg & 17 & 20 & 22 \\
\hline trivit $\mathrm{AD}_{3} \mathrm{E}, \mathrm{ml}$ & 0.34 & 0.36 & 0.38 \\
\hline retinyl acetate, $\mathrm{ml}$ & 0.22 & 0.25 & 0.28 \\
\hline \multicolumn{4}{|l|}{ The diet contains: } \\
\hline dry matter, kg & 9.1 & 9.4 & 9.8 \\
\hline exchange energy, MJ & 94 & 99 & 104 \\
\hline fodder units & 7.5 & 8.1 & 8.7 \\
\hline crude protein, $\mathrm{g}$ & 1,979 & 2,046 & 2,113 \\
\hline digestible protein, $\mathrm{g}$ & 1,395 & 1,446 & 1,497 \\
\hline crude fiber, $g$ & 2,212 & 2,231 & 2,249 \\
\hline starch, $g$ & 1,212 & 1,455 & 1,698 \\
\hline sugar, $\mathrm{g}$ & 100 & 118 & 135 \\
\hline crude fat, $g$ & 343 & 352 & 364 \\
\hline kitchen salt, g & 40 & 48 & 55 \\
\hline calcium, $\mathrm{g}$ & 52 & 56 & 60 \\
\hline phosphorus, $\mathrm{g}$ & 36 & 37 & 39 \\
\hline magnesium, $\mathrm{g}$ & 16 & 17 & 18 \\
\hline potassium, $g$ & 70 & 73 & 76 \\
\hline sulfur, $g$ & 15 & 16 & 16 \\
\hline copper, mg & 70 & 77 & 88 \\
\hline zinc, mg & 370 & 417 & 462 \\
\hline cobalt, mg & 5.0 & 5.6 & 6.2 \\
\hline manganese, $\mathrm{mg}$ & 372 & 388 & 403 \\
\hline vitamin $\mathrm{A}$, thousand IU & 62.8 & 70.0 & 78.0 \\
\hline vitamin $\mathrm{D}$, thousand IU & 6.8 & 7.4 & 7.4 \\
\hline vitamin $\mathrm{E}, \mathrm{mg}$ & 128 & 154 & 181 \\
\hline
\end{tabular}

Diets of the animals in all groups were identical, except for vitamin supplements that ensured the following levels of vitamin $\mathrm{A}$ in the diets (Table 2) [6].

Table 2: The level of vitamin A in diets

\begin{tabular}{|c|c|c|c|c|}
\hline \multirow{2}{*}{ Group } & \multicolumn{3}{|c|}{ Vitamin A, thousand IU/1000 kg of live weight } & \multirow{2}{*}{$\%$} \\
\hline & $300-350$ & $351-400$ & $401-450$ & \\
\hline I & 19 & 19 & 18 & 100 \\
\hline II & 24 & 23 & 23 & 125 \\
\hline III & 29 & 28 & 28 & 150 \\
\hline
\end{tabular}

Calves in group 1 received vitamin $\mathrm{A}$ in the amount equivalent to the standards of RAAS (1985) in terms of carotene (for cattle, $1 \mathrm{mg}$ of carotene is equivalent to $400 \mathrm{IU}$ of vitamin A), in group 2 - by $25 \%$, and in group $3-$ by $50 \%$ above the norm. The level of vitamin A was regulated at the expense of retinyl acetate solution in oil. Vitamin preparations in the form of aqueous emulsions were mixed with concentrates and fed to the calves once in a decade in the morning before the main feeding, which ensured complete palatability of the vitamin by the animals $[7,8]$.

\begin{tabular}{|l|c|c|c|}
\hline \multicolumn{1}{|c|}{ Table 3: Feeding diets for fattening calves on pulp } \\
\cline { 2 - 4 } \multicolumn{1}{|c|}{ Indicator } & \multicolumn{3}{|c|}{ Live weight, kg } \\
\cline { 2 - 4 } & $300-350$ & $351-400$ & $401-450$ \\
\hline Diet: & 40 & 37 & 35 \\
beet pulp, kg & 2.5 & 2.5 & 2.5 \\
spring straw, kg & 2.2 & 3.0 & 4.0 \\
barley groats, kg & 0.2 & 0.2 & 0.2 \\
grass meal, kg & 0.8 & 0.8 & 1.0 \\
molasses, kg & 45 & 55 & 60 \\
kitchen salt, g & 65 & 60 & 60 \\
carbonyl diamide, g & 55 & 60 & 45 \\
ammonium dibasic phosphate, g & 100 & 120 & 150 \\
copper sulfate, mg & 630 & 700 & 850 \\
zinc sulphate, mg & - & 260 & 400 \\
manganese sulfate, mg & 14 & 16 & 18 \\
cobalt chloride, mg & 0.37 & 0.39 & 0.40 \\
trivit AD3E, ml & 0.23 & 0.25 & 0.29 \\
retinyl acetate, ml & & & \\
\hline The diet contains: & 9.0 & 9.2 & 10.1 \\
dry matter, kg & 92 & 97 & 106 \\
exchange energy, MJ & 8.5 & 9.0 & 9.9 \\
fodder units & 1,081 & 1,115 & 1,157 \\
\hline crude protein, g & 688 & 721 & 748 \\
digestible protein, g & 1,930 & 1,899 & 1,904 \\
crude fiber, g & 1,072 & 1,460 & 1,945 \\
starch, g & & & \\
\hline
\end{tabular}

\begin{tabular}{|l|c|c|c|}
\hline sugar, g & 604 & 622 & 756 \\
crude fat, g & 195 & 205 & 222 \\
calcium, g & 56 & 54 & 54 \\
phosphorus, g & 25 & 28 & 30 \\
magnesium, g & 18 & 18 & 18 \\
potassium, g & 84 & 86 & 94 \\
sulfur, g & 12 & 13 & 14 \\
copper, g & 73 & 80 & 90 \\
zinc, g & 380 & 427 & 472 \\
manganese, mg & 328 & 380 & 480 \\
cobalt, mg & 5.1 & 5.7 & 6.3 \\
carotene, mg & 36 & 36 & 36 \\
vitamin A, thousand IU & 65.0 & 72.0 & 82.0 \\
vitamin D, thousand IU & 7.3 & 7.8 & 8.0 \\
vitamin E, mg & 130 & 170 & 221 \\
\hline
\end{tabular}

Table 4: Vitamin A level in the diets for fattening on pulp

\begin{tabular}{|l|c|c|c|c|}
\hline \multirow{2}{*}{ Group } & \multicolumn{2}{|c|}{ Vitamin A, thousand IU/100 kg of live weight } & $\%$ \\
\cline { 2 - 5 } & $300-350$ & $351-400$ & $401-450$ & \\
\hline I & 20 & 19 & 19 & 100 \\
II & 25 & 24 & 24 & 125 \\
III & 30 & 29 & 29 & 150 \\
\hline
\end{tabular}

Table 5: Diets of experimental calves for fattening on brewer's grains

\begin{tabular}{|c|c|c|c|}
\hline \multirow{2}{*}{ Indicator } & \multicolumn{3}{|c|}{ Live weight, $\mathrm{kg}$} \\
\hline & $300-350$ & $351-400$ & $401-450$ \\
\hline \multirow{8}{*}{$\begin{array}{l}\text { Diet: } \\
\text { brewer's grains, kg } \\
\text { brome hay, kg } \\
\text { barley groats, kg } \\
\text { molasses, kg } \\
\text { kitchen salt, g } \\
\text { fodder microvit A, mg } \\
\text { videin D3, mg }\end{array}$} & & & \\
\hline & 18 & 20 & 22 \\
\hline & 3 & 3.5 & 4 \\
\hline & 1.5 & 1.8 & 2 \\
\hline & 0.8 & 1 & 1 \\
\hline & 45 & 50 & 60 \\
\hline & 86 & 92 & 104 \\
\hline & 30 & 32 & 33 \\
\hline \multicolumn{4}{|l|}{ The diet contains: } \\
\hline Energetic Feed Units (EFU) & 8.6 & 10.0 & 11.0 \\
\hline Exchange energy, MJ & 86 & 100 & 110 \\
\hline Dry matter, $\mathrm{kg}$ & 8.4 & 9.6 & 10.7 \\
\hline Crude protein, $\mathrm{g}$ & 1,556 & 1,773 & 1,957 \\
\hline Digestible protein, $\mathrm{g}$ & 1,050 & 1,196 & 1,320 \\
\hline Crude fiber, $g$ & 1,683 & 1,917 & 2,146 \\
\hline Starch, g & 840 & 1,008 & 1,120 \\
\hline Sugar, g & 554 & 680 & 703 \\
\hline Fat, g & 281 & 317 & 350 \\
\hline Calcium, g & 41 & 47 & 52 \\
\hline Phosphorus, g & 23 & 28 & 32 \\
\hline Magnesium, g & 15 & 18 & 20 \\
\hline Potassium, $g$ & 67 & 81 & 88 \\
\hline Sulfur, g & 21 & 23 & 26 \\
\hline
\end{tabular}

When fattening on brewer's grains, calves in group 1 received vitamin $\mathrm{A}$ in the amount equivalent to the standards of RAAS in terms of carotene, group $2-$ by $20 \%$, and group $3-$ by $40 \%$ over the norm. In absolute terms, the dosage of vitamin $\mathrm{A}$ in group 1 was $19-20$ thousand IU per $100 \mathrm{~kg}$ of live weight, in group 2 23-24 thousand IU per $100 \mathrm{~kg}$ of live weight, and in group 3 $27-28$ thousand IU/100 $\mathrm{kg}$ of live weight (Table 6) [9].

Table 6: The level of vitamin $\mathrm{A}$ in diets

\begin{tabular}{|c|c|c|c|c|}
\hline \multirow{2}{*}{ Group } & \multicolumn{2}{|c|}{ Vitamin A, thousand IU/100 kg of live weight } & $\%$ \\
\cline { 2 - 5 } & $300-350$ & $351-400$ & $401-450$ & \\
\hline I & 20 & 19 & 19 & 100 \\
II & 24 & 23 & 23 & 120 \\
III & 28 & 27 & 27 & 140 \\
\hline
\end{tabular}

To determine veracious vitamin A status of the animals, scientists suggest examining the liver, in which up to $90-95 \%$ of the total amount of vitamin $\mathrm{A}$ is deposited, with the remaining amount concentrated in kidneys, internal fat, and in trace amounts it is found in muscles. The authors have found that before fattening on distiller's grains, liver of young cattle contained 24.72-26.34 $\mu \mathrm{g}$ of vitamin A per $\mathrm{g}$ of crude tissue, in case of fattening on pulp $22.46-23.64 \mu \mathrm{g} / \mathrm{g}$, in case of fattening on brewer's grains -67.58 $69.80 \mu \mathrm{g} / \mathrm{g}[10,11]$.

According to some scientists, it is below the physiological norm, and indicates latent form of A-hypovitaminosis. Introduction of vitamin $\mathrm{A}$ into the diet of calves in group 1 in the amount 
equivalent to the existing norm of RAAS (1985) in terms of carotene somewhat normalized vitamin feeding, vitamin A concentration by the end of fattening on distiller's grains increased by $51.4 \%$, by the end of fattening on pulp - by $20.7 \%$, by the end of fattening on brewer's grains - by $16.0 \%$, and amounted to 38.64 , 26.93 , and $80.75 \mu \mathrm{g} / \mathrm{g}$, respectively.

With increasing the dosages of vitamin $\mathrm{A}$, its reserves in the liver significantly increased. In group 2, concentration of vitamin A in case of fattening on distiller's grains was $57.64 \mathrm{mg} / \mathrm{g}$, on pulp $41.46 \mathrm{mg} / \mathrm{g}$, when fattening on brewer's grains $-157.86 \mu \mathrm{g} / \mathrm{g}$, in group $3-74.35,62.76$ and $172.06 \mu \mathrm{g} / \mathrm{g}$ of crude tissue, respectively. Such vitamin A content in the liver is typical for healthy animals, and speaks of good vitamin A metabolism in the organism (Table 7) [1, 12].

The most accessible indicator that characterizes the vitamin A status of an animal is the concentration of vitamin A in the blood serum. One should remember that blood counts have well-known limitations, as the content of vitamin $\mathrm{A}$ in the blood remains unchanged for a long time after the beginning of its amount reduction in the liver, and decreases sharply only after complete depletion of reserves of the vitamin in the organism. However, vitamin A concentration in the blood in case of insufficient income with food is relatively lower than in case of sufficient supply.

According to the data of the authors, vitamin A concentration in blood serum of calves in case of fattening on distiller's grains amounted to 261-284 $\mu \mathrm{g} / 1$ (Table 8).

Table 7: Vitamin A concentration in the liver, $\mu \mathrm{g} / \mathrm{g}$ of crude tissue

\begin{tabular}{|c|c|c|c|}
\hline \multirow{2}{*}{ Type of fattening } & \multicolumn{3}{|c|}{ Group } \\
\cline { 2 - 4 } & I & II & III \\
\hline Distiller's grains: & & & \\
\hline at the beginning & $25.52 \pm 1.50$ & $24.72 \pm 0.58$ & $26.34 \pm 0.72$ \\
\hline at the end & $38.64 \pm 0.65$ & $57.64 \pm 0.69$ & $74.35 \pm 0.82$ \\
\hline Pulp: & & & \\
\hline at the beginning & $22.46 \pm 0.81$ & $22.71 \pm 1.10$ & $23.64 \pm 0.87$ \\
\hline at the end & $26.93 \pm 0.89$ & $41.46 \pm 1.41$ & $62.76 \pm 1.34$ \\
\hline Brewer's grains: & & & \\
\hline at the beginning & $69.64 \pm 1.09$ & $67.58 \pm 0.59$ & $69.80 \pm 1.19$ \\
\hline at the end & $80.75 \pm 0.84$ & $157.86 \pm 3.37$ & $172.06 \pm 2.11$ \\
\hline
\end{tabular}

Table 8: Vitamin A concentration in calves' blood serum, $\mu \mathrm{g} / 1$

\begin{tabular}{|l|c|c|c|}
\hline \multirow{2}{*}{ Fattening period } & \multicolumn{3}{|c|}{ Group } \\
\cline { 2 - 4 } & I & II & III \\
\hline \multicolumn{4}{|c|}{ Fattening on distiller's grains } \\
\hline Beginning & $274 \pm 1.40$ & $261 \pm 2.12$ & $284 \pm 0.93$ \\
\hline Middle & $304 \pm 1.17$ & $367 \pm 0.74$ & $371 \pm 2.88$ \\
\hline End & $346 \pm 2.00$ & $489 \pm 2.58$ & $656 \pm 2.56$ \\
\hline \multicolumn{4}{|c|}{ Fattening on pulp } \\
\hline Beginning & $198 \pm 7.30$ & $204 \pm 3.80$ & $207 \pm 2.00$ \\
\hline Middle & $282 \pm 4.05$ & $344 \pm 4.90$ & $355 \pm 8.70$ \\
\hline End & $325 \pm 0.50$ & $448 \pm 12.50$ & $472 \pm 4.90$ \\
\hline \multicolumn{4}{|c|}{ Fattening on brewer's grains } \\
\hline Beginning & $274 \pm 0.81$ & $285 \pm 0.85$ & $279 \pm 0.72$ \\
\hline Middle & $586 \pm 0.80$ & $745 \pm 2.01$ & $832 \pm 1.72$ \\
\hline End & $610 \pm 1.31$ & $950 \pm 0.83$ & $1,000 \pm 1.71$ \\
\hline As reserve
\end{tabular}

As reserves of vitamin A in the liver restored, its concentration in the blood increased. When fattening on brewer's grains, it corresponded to the physiological norm in the calves in group 1 by the middle of fattening period, while in the animals fattened on pulp and distiller's grains - only by the end of fattening, and in groups 2 and 3 - In the middle of the fattening period [13, 14].

\section{Discussion and Results}

Improving animal nutrition on vitamin A contributed to normalization of general metabolism in the organism, as evidenced by blood biochemical studies.

Analysis of the obtained data has shown that in the blood of the calves that received increased levels of vitamin A, increased contents of hemoglobin and erythrocytes were noted, which spoke of a higher intensity of the redox processes in the organism.

Elevated levels of vitamin A in the diets contributed to increasing the total protein in blood serum. The most distinctive changes occurred in the protein spectrum. In the calves from group 2, albumin content increased when fattening on distiller's grains by $5.5 \%$, when fattening on pulp - by $6.5 \%$, when fattening on brewer's grains - by $6.0 \%$, in the third group - by $6.1,8.7$, and $5.2 \%$, respectively, which resulted in the increased albuminglobulin index.

An increased content of albumin in the blood indicates improved protein-generating function of the organism [15]

Elevated levels of vitamin A improved mineral metabolism in the organism, as evidenced by an increased calcium content in the blood serum of the calves in groups 2 and 3 fattened on distiller's grains - by 5.5 to $6.6 \%$, fattened on pulp - by 7.5 to $8.3 \%$, fattened on brewer's grains - by 14.8 to $16.9 \%$, and an increased content of inorganic phosphorus by 9.8 to $12.5 \%, 10.6$ to $12.4 \%$ and $7.0-8.1 \%$, respectively [16].

The research has shown that the elevated levels of vitamin A in the diets had positive effect on digestibility of all nutrients; however, the effect was not unambiguous. While in case of fattening on pulp, increasing vitamin A dosages in diets by $25 \%$ of the norm, reduced to carotene, promoted a veracious increase in the dry matter by $3.0 \%$, organic matter - by $3.4 \%$, protein - by $5.6 \%$, fat - by $3.4 \%$, fiber - by $4.6 \%(\mathrm{p}<0.05)$, in case of fattening on distiller's grains, protein increased by $3.5 \%$, fat - by $2.5 \%$, fiber - by $4.2 \%(\mathrm{p}<0.05)$, and in case of feeding on brewer's grains, dry matter increased by $3.2 \%$, organic matter - by $3.3 \%$, protein - by $4.1 \%$, fiber - by $2.6 \%$, and fat - by $4.4 \%$. Elevating the level of vitamin A by 40 to $50 \%$ in group 3 did not result in further improvement of nutrients' digestibility, these indicators remained virtually the same as in group $2[17,18,19]$.

The results of digestion trial have shown that with elevated by $25 \%$ level of vitamin $\mathrm{A}$ in the diet, nitrogen in the diet was used better in case of fattening on pulp. The organisms of calves in group 2 contained more vitamin A by $16.6 \%(\mathrm{p}<0.025)$, and the use of digested vitamin increased by $2.8 \%(\mathrm{p}<0.05)$. When calves were fattened on distiller's grains, similar elevation of vitamin A level in the diet promoted increased by $11.2 \%$ deposition of nitrogen, and the use of digested vitamin increased by

$1.18 \%$

$(\mathrm{p}<0.05)$. When calves were fattened on brewer's grains, elevation of vitamin A level in the diet of group 2 promoted increased by $13.7 \%$ deposition of nitrogen in the organism, and the use of digested vitamin increased by $1.98 \%(\mathrm{p}<0.05)$.

Studying calcium and phosphorus metabolism in calves, the authors have found that at elevated levels of vitamin A in the diets based on distiller's grains, a tendency to improving calcium metabolism was noted, while in case of fattening on pulp, its deposition increased by 18 to $26 \%$, and the use of digested vitamin increased by 5.8 to $5.3 \%$

A somewhat different picture was seen with phosphorus [20].

Elevated levels of vitamin A in the diets had positive effect on its use in both types of fattening; however, it was the most significant in case of fattening on pulp. Phosphorus deposition in the organisms of animals increased by 27.2 and $27.1 \%$, in case of fattening on distiller's grains - by 9.5 to $12.4 \%$, and the percentages of digested vitamin use were higher by 7.9 to $5.9 \%$ and 3.4 to $4.5 \%$, respectively.

As to fattening calves on brewer's grains, elevated levels of vitamin $\mathrm{A}$ in the diets by $20 \%$ resulted in significant increases in both calcium and phosphorus content by 12.6 and $15.9 \%$ (p < 0.01 ), respectively, and the percentage of use of the digested vitamin increased by 2.6 and $3.8 \%$ of eaten fodder.

Increasing the dosage of vitamin $\mathrm{A}$ in the diets by $40 \%$ resulted in further improvement in the use of these elements [21]. 


\section{Conclusion}

1. Optimization of vitamin A nutrition of calves had positive effect on the growth rate and meat productivity of animals.

2. Various levels of vitamin A had no significant effect on weight of bones and tendons.

3. Feeding diets with elevated level of vitamin A significantly increased the average content of dry matter and protein in an average sample of meat. No difference was noted in terms of fat and ash content among the groups.

\section{References}

[1] Valoshin AV (1997), Vliyanie A - obespechennosti zhomovih ratsionov na kontsentratsiyu tokoferolov $\mathrm{v}$ pecheni i sivorotke krovi bichkov [The effect of vitamin A presence in pulp diets on concentration of tocopherol in the liver and blood serum of calves]. Physiological and biological bases of animals' high productivity: coll. of scient. works. Saransk, pp: 112-113.

[2] Berzin NI (1988), Vzaimosvyaz vitamina A i tsinka v organizme zhivotnih [Correlation between vitamin A and zinc in the organism of animals]. Vestnik sel'skokhozyaystvennoy nauki [Bulletin of Agricultural Science], 1 (376), pp: 106-111.

[3] Valoshin AV (2012), Vitamin A status and productivity of calves fattened on brewer's grains. Bulletin of the Altai State Agrarian University 8 (94), pp: 95-98.

[4] Dusheiko AA (1989), Vitamin A: Obmen i funktsii [Vitamin A Metabolism and function]. Kiev, Naukova Dumka, 288 p.

[5] Williams JB, Pramonic BC, Napoli JL (1984), Vitamin A metabolism analysis of teadystatebneutral metabolites in rat tissues. The Journal of Lipid Research 25(6), pp: 638-645.

[6] Dvinskaya LM (1989), Vitaminnoe pitanie selskohozyaistvennih zhivotnih [Vitamin nutrition of agricultural animals]. Moscow, Agropromizdat, $183 \mathrm{p}$.

[7] Lebedev NI (1981), Otsenka sposobov primeneniya vitamina A bychkam [Assessing methods of using vitamin A for calves]. Dairy and meat cattle breeding, 12, pp: 43.

[8] Skurikhin VN, Dvinskaya LM, Ryabykh TE (1989), $\begin{array}{lll}\text { Mikrokolonochnaya vysokoeffektivnaya zhidkostnaya } & \end{array}$ khromatografiya vitamina A. Seriynoye opredeleniye v moloke i molozive [Microcolumn high performance liquid chromatography of vitamin A. Serial determination in milk and colostrum]. Vestnik sel'skokhozyaystvennoy nauki [Bulletin of Agricultural Science], 9, pp: 111-113.

[9] Lidak MY, Pletsity KD (1984), Vitamin A i sinteticheskie retinoidy $v$ immunologii $i$ ontologii [Vitamin A and synthetic retinoids in immunology and ontology]. Riga: Zinatne, $126 \mathrm{p}$

[10] Draganov IF (1986), Barda i pivnaya drobina v kormlenii skota ptitsi [Distiller's grains and brewer's grain in feeding livestock and poultry]. Moscow, Rosselkhozizdat, $136 \mathrm{p}$.

[11] Skurikhin VN., Dvinskaya LM., Ryabykh TE (1992), Opredeleniye karotinoidov v plazme krovi i tkanyakh sel'skokhozyaystvennykh zhivotnykh metodom vysokoeffektivnoy zhidkostnoy khromatografii [Determination of carotenoids in the blood plasma and tissues of farm animals by high performance liquid chromatography].

Bulletin of The All-Russian Research Institute of Physiology, Biology and Feeding (ARRIPBF) of agricultural animals, Issue 102, pp: 76-82.

[12] Pitt GA (1983), Chemical structure and the changing concept of vitamin A activity. The Proceedings of the Nutrition Society 42(1), pp: 43-51.

[13] Kalashnikov AP, Fisinin VI et al. (2003), Normy $i$ ratsiony selskohozyaistvennih zhivotnih [Norms and rations for agricultural animals]: Reference book. Moscow, $486 \mathrm{p}$.

[14] Keller HE (1982), Methods for Vitamins and Carotenoids in Feed. Rocher: Basle.

[15] Olson GA (1984), Serum levels of vitamin A and carotenoids as reflectors of nutritional status. Journal of the National Cancer Institute 73(6), pp: 139-144.

[16] Ross AC, Goodman DS (1979), Intracellular binding protein for retinol and retinoic acid: comparison with each other and with serum retinol-binding protein. Federation Proceedings 38(11), pp: 2515-2518.

[17] Lisunova LI (2011), Kormlenie selskohozyaistvennih zhivotnih [Feeding agricultural animals]. Novosibirsk, Zolotoy Kolos, 294 p.
[18] Manz V, Philipp K (1984), Analytical Methods for Vitamins and Carotenoids in Feed. Rocher, Basle.

[19] Fidge NH, Smith FR, Goodman DS (1969), Vitamin A and carotenoids: The enzymic conversion of beta-carotene into retinal in hog intestinal mucosa. Biochemical Journal 114(4), pp: 689-694.

[20] Petrushkin AI (1997), Optimizatsiya A - vitaminnogo pitaniya bichkov pri silosnom vide otkorma [Optimization of vitamin A nutrition of calves fattened on silage]: author's abstract of ... dis. of candidate of Agricultural Sciences. Saransk, $21 \mathrm{p}$.

[21] Mingazov TA (1983), Vliyanie vitamina a na vosproizvoditelnuyu funktsiyu korov [The effect of vitamin A on the reproductive function of cows]. Bulletin of agricultural sciences of Kazakhstan 8 , pp: 69-72. 